\title{
KOMPOSISI DAN KERAGAMAN JENIS BAJAKAH DI RESORT SEBANGAU HULU TAMAN NASIONAL SEBANGAU
}

\section{Composition and diversity of bajakah in sebangau hulu resort, Sebangau national park}

\author{
Belinda Hastari ${ }^{1}$, Robby Octavianus ${ }^{2}$. \\ ${ }^{1,2}$ Jurusan Kehutanan Fakultas Pertanian Universitas Palangka Raya \\ Kampus UPR Tunjung Nyaho Jl. Yos Sudarso-Palangka Raya Kalimantan Tengah \\ email : belinda.htari@gmail.com
}

\begin{abstract}
Sebangau National Park (TNS) is a conservation area for peatland ecosystems with biological natural resources including medicinal plant namely Bajakah. The aims of this study were to identified and measured composition and diversity level of Bajakah in TNS. Results of this study are expected to be data baseline for TNS' management especially conservation of Bajakah. Data was collected using observation method on 15 plots study with analysis on the parameters of the Important Value Index (IVI), Species Diversity and Species Evenness. Results of study recorded 6 species of bajakah in TNS, namely Akar Kuning, Bajakah Dango, Bajakah Darak, Bajakah Lunuk, Kalalawit Merah, and Kalalawit Putih. Based on IVI, Kalalawit Merah (Uncaria sp) is the most dominating (134,792\%), Species Diversity Index 1,36, and Species Evenness Index 0,759 .
\end{abstract}

Keywords : Bajakah, Sebangau National Park, Diversity

\begin{abstract}
Abstrak
Taman Nasional Sebangau (TNS) merupakan kawasan konservasi ekosistem lahan gambut beserta sumberdaya alam hayati dan keunikan di dalamnya yang menyimpan potensi sumberdaya hutan tanaman berkhasiat obat termasuk Bajakah. Penelitian ini bertujuan mengidentifikasi dan menghitung keragaman jenis tumbuhan Bajakah di TNS, Hasil penelitian ini diharapkan dapat menjadi baseline data guna pengelolaan kawasan TNS dalam hal tindak konservasi sumberdaya hutan khususnya Bajakah. Metode yang digunakan dalam penelitian yaitu observasi pada 15 plot ukur dengan analisis pada parameter Indeks Nilai Penting (INP), Indek Keragaman Jenis dan Kemerataan Jenis. Hasil penelitian menunjukan terdapat 6 (enam) jenis bajakah yang terdapat di TNS yaitu Akar Kuning, Bajakah Dango, Bajakah Darak, Bajakah Lunuk, Kalalawit Merah, dan Kalalawit Putih. Dominansi jenis ditunjukkan oleh Kalalawit Merah (Uncaria sp), Indeks Keragaman Jenis Bajakah 1,36 dan Indeks Kemerataan Jenis 0,759
\end{abstract}

Kata kunci : Bajakah, Taman Nasional Sebangau, Keragaman Jenis 


\section{PENDAHULUAN}

Keanekaragaman hayati hutan rawa gambut Kalimantan Tengah mempunyai peranan berperan penting sebagai penyimpan plasma nutfah yang beberapa di antaranya bersifat endemic (Hastuti dkk., 2014). Spesies tumbuhan yang tumbuh di areal rawa gambut sangat spesifik dan dan beberapa spesies di antaranya mempunyai nilai ekonomi yang tinggi, baik dari hasil kayunya maupun hasil non kayu seperti tumbuhan berkhasiat obat (Nugroho, 2012).

Bajakah adalah golongan liana dengan khasiat obat, yang dipercaya oleh masyarakat memiliki berbagai khasiat pengobatan salah satunya sebagai anti kanker. Sejak lama, tanaman obat menjadi upaya pengobatan alternatif selain pengobatan medis dikarenakan pertimbangan lebih murah dan rendah efek samping. Pada masa dan pasca wabah Covid-19, kecenderungan penggunaan tanaman obat tradisonal meningkat, tidak terkecuali tanaman Bajakah. Beberapa jenis akar Bajakah sejak lama dipercaya meningkatkan daya tahan tubuh, anti bakteri, mengatasi penyakit liver, penyakit malaria, diabetes dan penyakit kuning terkait gangguan hati, serta menyegarkan tubuh (Kalima, 2021; Paramita dan Tata, 2021).
Kawasan Taman Nasional Sebangau (TNS) merupakan kawasan konservasi ekosistem lahan gambut beserta sumberdaya alam hayati dan keunikan di dalamnya. Kawasan ini menjadi icon di provinsi Kalimantan Tengah yang mana salah satu potensi dalam kawasan adalah beraneka tanaman obat. Setidaknya terdapat 56 species tanaman obat di kawasan TNS dimana beberapa jenis akar bajakah termasuk didalamnya (Denny dan Kalima, 2016,). Jenis-jenis tanaman obat tersebut telah banyak dimanfaatkan masyarakat sekitar kawasan TNS baik secara tradisional maupun pemanfaatan dengan pengolahan modern sehingga juga menopang perekonomian masyarakat khususnya di kota Palangka Raya (Riyanti dkk, 2020).

Penelitian ini bertujuan mengidentifikasi dan menghitung keragaman jenis tanaman Bajakah dalam komposisinya di TNS. Penelitian ini diharapkan dapat menjadi baseline data guna meningkatkan pengelolaan, pemanfaatan serta pelestarian tumbuhan Bajakah di TNS.

\section{METODOLOGI PENELITIAN}

Penelitian ini dilaksanakan di kawasan TNS yaitu Resort Sebangau Hulu pada bulan Agustus 2021 dengan menggunakan metode observasi. Observasi dilakukan 
untuk mengidentifikasi dan mengukur potensi jenis akar Bajakah di TNS yaitu dengan membuat 15 plot ukur berukuran 20 m x 20 m yang diletakkan secara purposive pada lokasi yang mewakili habitat Bajakah. Parameter yang dicatat adalah jenis, diameter, jumlah individu tumbuhan Bajakah dan jenis pohon inang. Pengukuran diameter tanaman Bajakah dilakukan pada bagian batang yang berada $25 \mathrm{~cm}$ di atas sistem perakaran, sedangkan pengukuran diameter pohon inang dilakukan pada ketinggian $130 \mathrm{~cm}$ di atas permukaan tanah
(30 $\mathrm{cm}$ di atas banir). Identifikasi ini dilakukan dengan dua cara yaitu dengan studi pustaka beberapa buku dan jurnal penelitian, diantaranya Husson, dkk (2018); Paramita dan Tata (2021) dan dengan berdasarkan informasi dari masyarakat lokal sebagai pengenal jenis bajakah.

Analisis dilakukan dengan perhitungan parameter sebagaimana Tabel 1. yang meliputi:

1. Indeks Nilai Penting (INP)

2. Indeks Keanekaragaman Jenis $\left(\mathrm{H}^{\mathrm{ee}}\right)$

3. Indeks Kemerataan Jenis (E)

Tabel 1. Parameter Analisis

\begin{tabular}{|c|c|c|}
\hline Indeks & Rumus & Deskripsi \\
\hline INP & $\begin{array}{l}\text { Kerapatan Relatif }+ \text { Frekuensi Relatif }+ \\
\text { Dominansi Relatif }\end{array}$ & \\
\hline Kerapatan Relatif & $\frac{\text { Kerapatan suatu Jenis }}{\text { Kerapatan total seluruh jenis }} \times 100 \%$ & \\
\hline Kerapatan Jenis & $\frac{\text { Jumlah individu }}{\text { Luas plot contoh }}$ & \\
\hline Frekuensi Relatif & $\frac{\text { Frekuensi suatu jenis }}{\text { Frekuensi seluruh jenis }} \times 100 \%$ & \\
\hline Frekuensi Jenis & $\frac{\text { Jumlah plot contoh ditemukan suatu jenis }}{\text { Total plot contoh }}$ & \\
\hline Dominansi Relatif & $\frac{\text { Dominansi suatu jenis }}{\text { Dominansi seluruh jenis }} x 100$ & \\
\hline Dominansi Jenis & $\frac{\text { Luas bidang dasar suatu jenis }}{\text { Luas plot contoh }}$ & \\
\hline $\begin{array}{l}\text { Indeks Keragaman } \\
\text { Jenis }\left(H^{\prime}\right)\end{array}$ & $\begin{array}{l}\mathrm{H}^{\prime}=-\sum_{i=1}\left(\frac{\mathrm{ni}}{\mathrm{N}}\right) \ln \left(\frac{\mathrm{ni}}{\mathrm{N}}\right) \\
\mathrm{H}^{\prime}=\text { Shannon }- \text { Wiener Index } \\
\mathrm{ni}=\text { Jumlah Individu dalam satu jenis } \\
\mathrm{N}=\text { Total Jumlah individu jenis yang } \\
\text { ditemukan }\end{array}$ & $\begin{array}{l}\text { Besaran } \mathrm{H}^{\prime}<1,5 \\
\text { menunjukkan } \\
\text { keanekaragaman jenis } \\
\text { tergolong rendah, H' }= \\
1,5-3,5 \text { menunjukkan } \\
\text { keanekaragaman jenis } \\
\text { tergolong sedang dan H' } \\
>\quad 3,5 \text { menunjukkan }\end{array}$ \\
\hline
\end{tabular}




\begin{tabular}{lll}
\hline & & $\begin{array}{l}\text { keanekaragaman } \\
\text { tergolong tinggi. }\end{array}$ \\
\hline $\begin{array}{l}\text { Indeks kemerataan } \\
\text { Jenis (E) }\end{array}$ & $\mathrm{E}=\frac{\mathrm{H}^{\prime}}{\ln \mathrm{S}}$ & $\begin{array}{l}\text { Besaran } \mathrm{E}^{\prime}<0.3 \\
\text { menunjukkan kemerataan }\end{array}$ \\
& $\mathrm{E}=$ Index of Species Evenness $(0-1)$ & $\begin{array}{l}\text { jenis tergolong rendah, } \mathrm{E}^{\prime} \\
=0.3-0.6 \text { kemerataan }\end{array}$ \\
& $\mathrm{H}^{\prime}=$ Shannon-Wiener Index & $\begin{array}{l}\text { jenis tergolong sedang } \\
\text { dan E' }>0.6 \text { maka }\end{array}$ \\
$\mathrm{S}=$ Jumlah Jenis & $\begin{array}{l}\text { kemerataaan jenis } \\
\text { tergolong tinggi. }\end{array}$ \\
\hline
\end{tabular}

\section{HASIL DAN PEMBAHASAN}

A. Keanekaragaman Jenis Bajakah Bajakah tergolong sebagai Liana yaitu golongan tumbuhan merambat yang berakar pada tanah, dalam pertumbuhannya menggunakan berbagai jenis pohon untuk merambat sehingga beberapa jenisnya dapat mencapai lapisan tajuk agar dapat menjulang dan daunnya memperoleh cahaya matahari maksimum (Indriyanto, 2006; Asriani dkk, 2008). Keberadaan liana di hutan merupakan karakteristik dari hutanhutan tropis basah. Bajakah sendiri termasuk dalam golongan Liana bersulur (tendril lianas) yaitu tumbuhan yang mempunyai organ tumbuh berupa sulur-sulur yang dihasilkan secara khusus untuk membantu liana memanjat pada tumbuhan penopang (Indriyanto, 2006).

B. Hasil penelitian menunjukkan terdapat 6 (enam) jenis Bajakah yang ditemukan di kawasan Taman Nasional Sebangau, 1 diantaranya hanya dikenali nama lokalnya saja. Jenis-jenis Bajakah ini didominasi oleh Bajakah jenis Kalalawit Merah (Uncaria sp) yang ditunjukkan dengan INP tertinggi pada jenis tersebut yaitu $134,792 \%$. Analisis indeks keanekaragaman jenis Bajakah di areal penelitian menunjukkan indeks keanekaragaman jenis yang rendah, dengan indeks kemerataan jenis tinggi. 
Tabel 1. Jenis Bajakah di Resort Sebangau Hulu TNS

\begin{tabular}{ccccc}
\hline No & Nama Lokal & Nama Ilmiah & Famili & INP (\%) \\
\hline 1. & Akar Kuning & $\begin{array}{c}\text { Fibraurea tinctoria } \\
\text { Laur }\end{array}$ & Menispermaceae & 59,611 \\
\hline 2. & Bajakah Dango & Willugghbeia $s p$ & Apocynaceae & 7,816 \\
\hline 3. & Bajakah Darak & - & - & 39,038 \\
\hline 4. & Bajakah Lunuk & Ficus $s p$ & Moraceae & 16,357 \\
\hline 5. & Kalalawit Merah & Uncaria $s p$ & Rubiaceae & 134,792 \\
\hline 6. & Kalalawit Putih & Salacia $s p$ & Celastraceae & 42,387 \\
\hline
\end{tabular}

Tabel 2 . Indeks Keanekaragaman Jenis Bajakah

\begin{tabular}{clr}
\hline No & \multicolumn{1}{c}{ Jenis Indeks } & \multicolumn{1}{c}{ Nilai } \\
\hline 1. & Indeks Keragaman Jenis Shanon-Wiener $\left(\mathrm{H}^{\prime}\right)$ & 1,36 \\
\hline 2. & Indeks Kemerataan Jenis $\left(\mathrm{E}^{\prime}\right)$ & 0,759
\end{tabular}

Kalalawit Merah (Uncaria sp) mempunyai nilai penting tertinggi (Tabel 1) dan ditemukan tersebar di 13 (tiga belas) plot dari keseluruhan 15 plot. Akar Kuning (Fibraurea tinctoria Laur) dan Kalalawit Putih (Salacia sp) adalah jenis Bajakah lainnya yang juga mendominasi. Indeks Nilai Penting (INP) menunjukkan peranan jenis tersebut dalam kawasan. Jenis yang mempunyai INP paling besar dapat dikatakan berperan penting di dalam kawasan tersebut. Jenis ini mempunyai pengaruh paling dominan terhadap perubahan kondisi lingkungan maupun keberadaan jenis lainnya dalam kawasan. Jenis-jenis yang mendominasi juga menunjukkan memiliki peluang pertumbuhan untuk kelangsungan hidup terbaik (Tata dan Pradjadinata, 2016).
Indeks keragaman jenis Bajakah di lokasi penelitian adalah 1,36. Nilai ini menunjukkan keragaman jenis di kawasan ini rendah. Sebaliknya Indeks Kemerataan Jenis adalah 0,759 yang dapat digolongkan tinggi. Secara ekologis nilai keragaman dan kemerataan jenis Bajakah di lokasi penelitian ini menandakan bahwa komunitas tergolong besar meskipun rendah keragaman jenisnya. Menurut Ludwig dan Reynolds (1988), suatu komunitas dikatakan mempunyai keragaman tinggi jika terdiri dari banyak jenis dengan kelimpahan sama atau hampir sama.

Keanekaragaman jenis cenderung akan rendah terutama pada ekosistemekosistem yang secara fisik terkendali dan sebaliknya tinggi terutama pada ekosistem 
yang diatur secara biologi (Odum, 1993). Lokasi penelitian yaitu di Resort Sebangau Hulu adalah merupakan bagian dari zona pemanfaatan di TNS dimana dikembangkan kegiatan ekowisata, penelitian serta menjadi tempat pemungutan Bajakah oleh masyarakat sekitar. Kondisi ini diduga menjadi salah satu penyebab rendahnya keragaman jenis Bajakah pada lokasi tersebut, selain juga faktor lingkungan makro dan mikro.

Indeks kemerataan menggambarkan bagaimana meratanya sebaran individu dari spesies organisme yang menyusun komunitas, dan menggambarkan kestabilan suatu komunitas. Nilai indeks kemerataan (E) berkisar antara 0-1 yang mana semakin kecil nilai $\mathrm{E}$ atau mendekati nol, maka semakin tidak merata penyebarannya dalam komunitas tersebut dan sebaliknya semakin besar nilai E atau mendekati satu, maka organisme dalam komunitas menyebar secara merata (Daget, 1976). Indeks kemerataan pada Tabel 2 menunjukan spesies Bajakah di lokasi penelitian termasuk ke dalam komunitas stabil. Dapat dikatakan, bahwa populasi antara spesies Bajakah yang ada di Resort Sebangau Hulu cukup merata sehingga lebih stabil dan dapat kembali ke keadaan semula ketika mendapat gangguan.
Komunitas dengan keanekaragaman tinggi akan lebih mantap terhadap gangguan lingkungan/iklim. Keanekaragaman cenderung meningkat pada komunitas yang lebih tua dan keanekaragaman rendah pada komunitas yang baru terbentuk (Odum, 1993).

Secara umum belum dapat dijelaskan dengan pasti tentang fenomena struktur dan komposisi Bajakah di kawasan TNS dikarenakan minim dan sangat terbatasnya penelitian ekologi Bajakah, peneliti belum menemukan penelitian yang menjelaskan ekologi Bajakah terutama di TNS. Meski demikian komposisi Bajakah dapat dihubungkan dengan keadaan tutupan tajuk hutan maupun tanah di lokasi penelitian serta struktur vegetasi kawasan TNS yang sangat beragam. Iklim mikro yang terjadi sangat ditentukan oleh rapatnya vegetasi dan tutupan tajuk hutan. Tutupan tajuk di TNS yang cukup rapat didominasi oleh vegetasi hutan rawa gambut seperti Balangeran, Pampaning, Tutup Kabali, Ramin, dll; yang menjadi pohon inang sangat menentukan dalam dinamika komunitas liana termasuk golongan Bajakah (Lampiran 1). Tutupan tajuk dari pohonpohon yang terdapat di kawasan TNS memberikan naungan yang cukup bagi Bajakah. Sebanyak 33 jenis pohon inang 
digunakan Bajakah di TNS untuk bertumbuh, dimana jenis Kalalawit Merah menggunakan jenis pohon inang terbanyak. Hal ini sebagaimana dijelaskan Viktor dkk (2016) dalam penelitiannya bahwa naungan oleh populasi Merbau di hutan Gunung Meja Manokwari memainkan peranan penting dalam dinamika komunitas liana melalui posisinya pada strata paling atas yaitu strata A dan B sehingga memberikan naungan yang cukup bagi liana. Lebih jauh dijelaskan bahwa ukuran diameter dan tinggi Merbau memudahkan liana menjadikannya sebagai pohon inang. Karakter pohon inang mempunyai peran yang cukup penting pada kepadatan liana (Malizia dkk, 2010); semakin besar diameter pohon inang akan meningkatkan jumlah liana yang bergantung padanya (Homeier dkk., 2010). Secara keseluruhan, kelimpahan liana meningkat dengan peningkatan diameter batang pohon inang, sedangkan jenis pohon inang tidak memberikan perbedaan.

Faktor tanah di kawasan TNS yaitu rawa gambut diduga menjadi alasan rendahnya keragaman jenis Bajakah. Tanah yang kaya akan nutrisi sangat berpengaruh pada kepadatan dan keragaman jenis liana. Menurut Nurfazliza dkk (2012), kehadiran beberapa jenis liana di hutan dataran rendah Negeri Sembilan, dihubungkan dengan faktor $\mathrm{pH}$ tanah, bahan organik total, bahan organik tersedia seperti $\mathrm{Mg}, \mathrm{K}$ dan P. Famili dengan jenis paling banyak yang ditemukan adalah annonaceae dengan 33 jenis (Nurfazliza dkk., 2012). Riduan dkk (2019) dalam penelitiannya di Taman Nasional Gunung Palung menemukan bahwa terdapat jenis liana Bajakah Willugghbeia sp; yaitu dikenal sebagai Bajakah Dango di TNS, dimana keanekaragaman jenis liana tertinggi adalah pada tanah Alluvial diikuti oleh tipe hutan rawa gambut-air tawar, sejalan dengan itu ditemukan Bajakah jenis Akar kuning (Fibraurea tinctoria Laur) di tanah gambut Taman Nasional Sebangau (Lestariningsih dkk,2018) dan hutan rawa gambut Blok Release Kabupaten Kapuas Kalimantan Tengah (Kalima, 2021).

Faktor lainnya yang dapat dijelaskan untuk menggambarkan keberadaan Bajakah di TNS adalah terkait iklim, yaitu cahaya dan temperatur udara serta curah hujan. Iklim yang sejuk di bawah tegakan hutan, suplai air yang tercukupi dari curah hujan serta intensitas cahaya yang tinggi selain mempengaruhi kepadatan dan keragaman juga mempengaruhi pola-pola spasial liana di hutan tropis (Nogueira dkk., 2011). Dijelaskan Carrasco-Urra dan Gianoli (2009), bahwa ketersediaan cahaya dalam 
hutan tidak mempengaruhi kelimpahan liana tak berkayu ketika jumlah dan ukuran pohon inang diperhitungkan; karena liana menggunakan pohon inang untuk mencapai tempat tertinggi yang menyediakan cahaya, artinya liana tidak menunggu cahaya optimal mencapai lantai hutan, melainkan berkompetisi untuk mendapatkan cahaya di atas tajuk hutan.

Struktur vegetasi juga turut mempengaruhi tumbuhan liana termasuk Bajakah. Struktur vegetasi berperan dalam mengontrol iklim mikro dalam waktu yang lama, terutama atas perubahan kandungan nutrisi tanah hutan bagi liana. Liana menyukai tumbuh di gap hutan dimana terjadinya gangguan pada struktur hutan. Pola spasial komunitas liana di hutan tropis berhubungan erat dengan struktur vegetasi (Nogueira dkk, 2011), bahwa peningkatan formasi gap hutan pada hutan tropis yang sudah berkembang akan mempengaruhi struktur dan kepadatan liana (Malizia dkk, 2010).

Melihat rendahnya keragaman jenis Bajakah di kawasan, perlu dikaji interaksi jenis-jenis Bajakah tersebut dengan pohon inang, mengingat Bajakah di TNS juga menjadi sumberdaya hutan yang dimanfaatkan oleh masyarakat sekitar . terutama sebagai langkah konservasi sumberdaya alam hayati tanaman berkhasiat obat.

\section{KESIMPULAN}

\section{Kesimpulan}

Taman Nasional Sebangau mengandung 6 jenis tumbuhan Bajakah, yaitu Akar Kuning, Bajakah Dango, Bajakah Darak, Bajakah Lunuk, Kalalawit Merah, dan Kalalawit Putih dengan jenis Kalalawit Merah mendominasi. Indeks Keragaman Jenis Bajakah di kawasan ini rendah sebaliknya Indeks Kemerataan Jenis tergolong tinggi. Sebanyak 33 jenis pohon inang turut berperan dalam menentukan kepadatan serta dinamika dalam komunitas Bajakah di TNS.

Upaya konservasi tumbuhan Bajakah tidak terlepas dari upaya konservasi tumbuhan inangnya, yang merupakan local species di hutan rawa gambut TNS.Perlu dikaji lebih lanjut asosiasi dan interaksi antar species pohon inang dan Bajakah di TNS.

\section{DAFTAR PUSTAKA}

Asrianny, Marian., dan Oka, N.P. 2008. Keanekaragaman Dan Kelimpahan Jenis Liana (Tumbuhan Memanjat) Pada Hutan Alam Di Hutan Pendidikan Universitas Hasanuddin 
Makassar. Jurnal Perennial. 5(1): 2330.

Carrasco-Urra, F., dan Gianoli, E., 2009. Abundance of Climbing Plants in a Southern Temperate Rain Forest: Host Tree Characteristics or Light Availability? Journal of Vegetation Science, 20(6):1155-1162.

Daget, J. 1976. Les Modèles Mathématiques en Ecologie. Masson, Paris.

Denny dan T. Kalima. 2016. Keanekaragaman Tumbuhan Obat pada Hutan Rawa Gambut Punggualas, Taman Nasional Sebangau, Kalimantan Tengah. Bul. Plasma Nutfah, 22(2):137-148.

Hastuti, S., A. Muin, dan E. Thamrin. 2014. Keanekaragaman Jenis Vegetasi Pada Hutan Rawa Gambut Sekunder Dan Belukar Rawa Desa Sungai Pelang, Kabupaten Ketapang. J. Hutan Lestari 2(3):435-443.

Husson, S.J, S.H. Limin, Adul, N.S. Boyd, J.J. Brousseau, S. Collier, S.M. Cheyne, L.J. D’Arcy, R.A. Dow, N.W. Dowds, M.L. Dragiewicz, D.A. Ehlers Smith, Iwan, Hendri, P.R. Houlihan, K.A. Jeffers, B.J.M. Jarrett, I.P. Kulu, H.C. Morrogh-Bernard, S.E. Page, E.D. Perlett, A. Purwanto, B. Ripoll
Capilla, Salahuddin, Santiano, S.J.J. Schreven, M.J. Struebig, S.A. Thornton, C. Tremlett, Z. Yeen and M.E. Harrison. 2018. Biodiversity Of The Sebangau Tropical Peat Swamp Forest, Indonesian Borneo. Mires and Peat, Volume 22 : 1-50. International Mire Conservation Group and International Peatland Society Heddy, Suswano. 1994. Prinsip-Prinsip Dasar Ekologi. PT Raja Grafindo Persada. Jakarta.

Herianto, Z.Kusuma, E.Nihayati, C.Prayogo. (2018). The Plant Wisdom Of Dayak Ot Danum, Central Kalimantan. J.Trop.Life Sience (JTLS), 8 (2) :130143

Homeier, J., Englert, F., Leuschner, C., Weigelt, P., dan Unger, M., 2010. Factors Controlling The Abundance of Lianas Along An Altitudinal Transect of Tropical Forests in Ecuador. Forest Ecology and Management, 259:1399-1405.

Indriyanto. 2006. Ekologi Hutan.Bumi Aksara. Jakarta.

Kalima, T. 2021. Potensi Akar Kuning (Fibraurea Tinctoria Lour.) Di Hutan Rawa Gambut, Kabupaten Kapuas, Provinsi Kalimantan Tengah . Jurnal 
Penelitian Hutan Tanaman, 18 (1): 13 34

Ludwig, J.A., dan Reynolds, J.F., 1988. Statistical Ecology: A Primer on Method and Computing. John Wiley \& Sons, Inc., New York

Lestariningsih N., Fitri Handayani dan Salasiah. 2018. Karakteristik Tanah Gambut Dan Keanekaragaman Tumbuhan Tinggi Di Taman Nasional Sebangau Kalimantan Tengah. BIOSFER Jurnal Tadris Pendidikan Biologi, 9 (1) : 114-139

Malizia, A., Grau, H.R., dan Lichstein, J.W., 2010. Soil Phosphorus and Disturbance Influence Liana Communities in A Subtropical Montane Forest. Journal of Vegetation Science, 21(3):551-560.

Nugroho, A.W. 2012. Struktur Vegetasi

Dan Komposisi Jenis Pada Hutan Rawa Gambut di Resort Habaring Hurung, Taman Nasional Sebangau, Kalimantan Tengah. Dalam: N. Sumedi, K. Sidiyasa, M. Turjaman, H.L. Tata, T.E. Komar, M. Wardani, H. Gunawan, I.W.S. Dharmawan, dan Kuntadi, editor, Prosiding Seminar Hasil-hasil Penelitian BPTKSDA Hasil-hasil Riset untuk Mendukung Konservasi yang Bermanfaat dan
Pemanfaatan yang Konservatif. hlm. 201-210.

Nogueira, A., Costa, F.R.C., dan Castilho, C.V., 2011. Liana Abundance Patterns: The Role of Ecological Filters During Development. Biotropica, 43(4):442449.

Odum, Eugene.P. 1993. Dasar-dasar Ekologi. Buku. Gajah Mada University Press. Yogyakarta.

P.P Paramita dan H L Tata. 2021. Phytochemical Compounds Identification Of Three Bajakah Species (Salacia Sp., Uncaria Acida, And Uncaria Gambir) Using GC-MS Pyrolysis. IOP Conf. Series: Earth and Environmental Science 762.

Riduwan, H. Prayogo, L. Sisillia. 2019. Studi Keanekaragaman Jenis Tumbuhan Liana Sebagai Sumber Pakan Primata Di Stasiun Penelitian Cabang Panti Taman Nasional Gunung Palung. Jurnal Hutan Lestari, 7 (1) : $296-304$

Riyanti, N. M.R.Satia, Muh.Azhari, 2020. Analisis Pengelolaan Sumber Daya Alam Sebagai Sumber Pendapatan Ekonomi Masyarakat Lokal Di Sempadan Sungai Rungan Kota 
Palangka Raya. Pencerah Publik, 7 (12) : 11-24

Tata, H.L., dan Pradjadinata, S. 2016. Native Species For Degradaded Peat Swamp Forest Rehabilitation. Silvikultur Tropika, 7(3), 80-82.

Viktor E.Sirami, Djoko Marsono, Ronggo Sadono dan M.Ali Imron. 2016.
Struktur, Keragaman Dan Asosiasi Komunitas Tumbuhan Pemanjat Dengan Populasi Alam Merbau Di Taman Wisata Alam Gunung Meja Manokwari-Papua Barat. J.Manusia dan Lingkungan Vol. 23(1) : 82-9 


\section{Lampiran 1. Jenis Pohon Inang Bajakah di Resort Sebangau Hulu TNS}

\begin{tabular}{|c|c|c|}
\hline No & Nama Jenis Pohon Inang & Nama Ilmiah \\
\hline 1 & Mangkinang Balawau & Elaeocarpus $s p$ \\
\hline 2 & Kahui/Belangeran & Shorea belangeran Burk \\
\hline 3 & Bintan & Licania splendens Korth. \\
\hline 4 & Daha Merah & $\begin{array}{l}\text { Horsfieldia crassifolia (Hook.f.\& Thomson) } \\
\text { Warb }\end{array}$ \\
\hline 5 & Daha Putih & Gymnacranthera farquhariana Warb \\
\hline 6 & Gantalang & Garcinia parvifolia Miq. \\
\hline 7 & Jambu Burung & Syzygium chloranthum Merr. \\
\hline 8 & Kajalaki & Aglaia rubiginosa (Hiern) Pannell \\
\hline 9 & Kajunjung & Cryptocarya griffithiana Wight, Icon. \\
\hline 10 & Kamasira & Ilex cymosa Bl. \\
\hline 11 & Karipak & Mezzettia parviflora Becc., NuovoGiorn. \\
\hline 12 & Katiau & Madhuca motleyana (de Vriese) J.F.Macbr. \\
\hline 13 & Kayu Kulat & Stemonurus scorpioides Becc. \\
\hline 14 & Kayu tabung & Ternstromia $s p$ \\
\hline 15 & Kelanis & Mastixia sp \\
\hline 16 & Lunuk & Ficus sp. \\
\hline 17 & Madang Perawas & Litsea lancifolia (Roxb. ex Wall.)Hook.f. \\
\hline 18 & Mahalilis & Palaquium rostratum (Miq.)Burck, Ann. Jard. \\
\hline 19 & Malabawi & Dacryodes rugosa (Bl.) H.J. Lam, Ann. \\
\hline 20 & Malam malam & Diospyros wallichii King \& Gamble \\
\hline 21 & Meranti padi & Shorea bracteolata Dyer, Fl. \\
\hline 22 & Pampaning & Lithocarpus conocarpus (Oudem.)Rehd. \\
\hline 23 & Parut & Calophyllum pisiferum Planchon \& Triana \\
\hline 24 & Piais & Nephelium maingayi Hiern \\
\hline 25 & Punguan & Cryptocarya griffithiana Wight, Icon. \\
\hline 26 & Rahanjang & Xylopia fusca Hook F.\&Thomson \\
\hline 27 & Ramin & Gonystylus bancanus (Miq) Kurz. \\
\hline 28 & Sagagulang & Blumeodendron tokbrai Bl. \\
\hline 29 & Sintuk & Elaeocarpus sp \\
\hline 30 & Tampang gagas & Unknown \\
\hline 31 & Terantang & Campnosperma coriaceum (Jack) Hall. \\
\hline 32 & Tutup Kabali & Diospyros areolata King \& Gamble \\
\hline 33 & Uweh & Syzygium longiflorum Presl, Bot. \\
\hline
\end{tabular}




\section{Lampiran 2. Jenis pohon inang pada Bajakah per plot pengamatan}

\begin{tabular}{|c|c|c|c|}
\hline Plot & No & Nama Jenis Bajakah & Nama Jenis Pohon Inang \\
\hline \multirow[t]{7}{*}{1} & 1 & Kalalawit Putih & Rahanjang \\
\hline & 2 & Kalalawit Putih & Jambu Burung \\
\hline & 3 & Kalalawit Merah & Pampaning \\
\hline & 4 & Akar Kuning & Gantalang \\
\hline & 5 & Bajakah Darak & Malam malam \\
\hline & 6 & Bajakah Dango & Belangeran \\
\hline & 7 & Bajakah Lunuk & Beringin \\
\hline \multirow[t]{10}{*}{2} & 1 & Kalalawit Merah & Rahanjang \\
\hline & 2 & Kalalawit Merah & Pampaning \\
\hline & 3 & Kalalawit Merah & Pampaning \\
\hline & 4 & Kalalawit Merah & Gantalang \\
\hline & 5 & Kalalawit Merah & Malam malam \\
\hline & 6 & Kalalawit Merah & Belangeran \\
\hline & 7 & Kalalawit Merah & Karipak \\
\hline & 8 & Kalalawit Merah & Tutup Kabali \\
\hline & 9 & Kalalawit Merah & Belangeran \\
\hline & 10 & Kalalawit Merah & Belangeran \\
\hline \multirow[t]{10}{*}{3} & 1 & Kalalawit Merah & Rahanjang \\
\hline & 2 & Kalalawit Merah & Jambu Burung \\
\hline & 3 & Kalalawit Putih & Pampaning \\
\hline & 4 & Kalalawit Merah & Gantalang \\
\hline & 5 & Kalalawit Merah & Malam malam \\
\hline & 6 & Bajakah Darak & Belangeran \\
\hline & 7 & Kalalawit Merah & Karipak \\
\hline & 8 & Akar Kuning & Sagagulang \\
\hline & 9 & Kalalawit Merah & Belangeran \\
\hline & 10 & Akar Kuning & Belangeran \\
\hline \multirow[t]{3}{*}{4} & 1 & Kalalawit Merah & Uweh \\
\hline & 2 & Kalalawit Merah & Kayu laki \\
\hline & 3 & Kalalawit Merah & Sagagulang \\
\hline
\end{tabular}




\begin{tabular}{|c|c|c|c|}
\hline & 4 & Akar Kuning & Ramin \\
\hline & 5 & Akar Kuning & Mangkinang Balawau \\
\hline & 6 & Akar Kuning & Kayu Kulat \\
\hline & 7 & Kalalawit Merah & Kamasira \\
\hline & 8 & Kalalawit Merah & Meranti padi \\
\hline & 9 & Bajakah Darak & Terantang \\
\hline \multirow[t]{9}{*}{5} & 1 & Kalalawit Merah & Meranti padi \\
\hline & 2 & Kalalawit Merah & Terantang \\
\hline & 3 & Kalalawit Merah & Mahalilis \\
\hline & 4 & Bajakah Darak & Sagagulang \\
\hline & 5 & Bajakah Lunuk & Beringin \\
\hline & 6 & Bajakah Dango & Punguan \\
\hline & 7 & Kalalawit Putih & Ramin \\
\hline & 8 & Akar Kuning & Terantang \\
\hline & 9 & Kalalawit Merah & Daha Merah \\
\hline \multirow[t]{6}{*}{6} & 1 & Kalalawit Merah & Terantang \\
\hline & 2 & Kalalawit Merah & Meranti padi \\
\hline & 3 & Kalalawit Merah & Sagagulang \\
\hline & 4 & Kalalawit Merah & Tutup kabali \\
\hline & 5 & Kalalawit Merah & Sagagulang \\
\hline & 6 & Kalalawit Merah & Sagagulang \\
\hline \multirow[t]{7}{*}{7} & 1 & Akar Kuning & Daha Putih \\
\hline & 2 & Bajakah Darak & Tampang gagas \\
\hline & 3 & Bajakah Darak & Sintuk \\
\hline & 4 & Bajakah Darak & Daha Putih \\
\hline & 5 & Akar Kuning & Mangkinang Balawau \\
\hline & 6 & Kalalawit Putih & Piais \\
\hline & 7 & Bajakah Lunuk & Lunuk \\
\hline \multirow[t]{5}{*}{8} & 1 & Kalalawit Merah & Kayu Kulat \\
\hline & 2 & Bajakah Lunuk & Lunuk \\
\hline & 3 & Akar Kuning & Terantang \\
\hline & 4 & Akar Kuning & Malabawi \\
\hline & 5 & Akar Kuning & Punguan \\
\hline
\end{tabular}




\begin{tabular}{|c|c|c|c|}
\hline & 6 & Akar Kuning & Kaja laki \\
\hline & 7 & Bajakah Lunuk & Lunuk \\
\hline & 8 & Kalalawit Merah & Kajunjung \\
\hline \multirow[t]{6}{*}{9} & 1 & Kalalawit Putih & Daha Merah \\
\hline & 2 & Kalalawit Putih & Terantang \\
\hline & 3 & Kalalawit Putih & Punguan \\
\hline & 4 & Kalalawit Putih & Punguan \\
\hline & 5 & Kalalawit Putih & Mangkinang Balawau \\
\hline & 6 & Kalalawit Putih & Punguan \\
\hline \multirow[t]{7}{*}{10} & 1 & Kalalawit Merah & Kayu Kulat \\
\hline & 2 & Akar Kuning & Ramin \\
\hline & 3 & Kalalawit Merah & Kajunjung \\
\hline & 4 & Akar Kuning & Kayu tabung \\
\hline & 5 & Kalalawit Merah & Ramin \\
\hline & 6 & Akar Kuning & Madang Perawas \\
\hline & 7 & Kalalawit Merah & Terantang \\
\hline \multirow[t]{9}{*}{11} & 1 & Kalalawit Merah & Mahalilis \\
\hline & 2 & Bajakah Darak & Tutup kabali \\
\hline & 3 & Bajakah Darak & Punguan \\
\hline & 4 & Bajakah Darak & Parut \\
\hline & 5 & Bajakah Darak & Kamasira \\
\hline & 6 & Kalalawit Merah & Sagagulang \\
\hline & 7 & Kalalawit Merah & Sagagulang \\
\hline & 8 & Kalalawit Merah & Terantang \\
\hline & 9 & Kalalawit Merah & Ramin \\
\hline \multirow[t]{7}{*}{12} & 1 & Kalalawit Merah & Ramin \\
\hline & 2 & Kalalawit Merah & Piais \\
\hline & 3 & Kalalawit Merah & Tutup kabali \\
\hline & 4 & Kalalawit Merah & Kamasira \\
\hline & 5 & Kalalawit Merah & Gantalang \\
\hline & 6 & Kalalawit Putih & Terantang \\
\hline & 7 & Kalalawit Putih & Kayu Kulat \\
\hline 13 & 1 & Kalalawit Merah & Tutup kabali \\
\hline
\end{tabular}




\begin{tabular}{|c|c|c|c|}
\hline & 2 & Kalalawit Merah & Punguan \\
\hline & 3 & Kalalawit Merah & Uweh \\
\hline & 4 & Kalalawit Merah & Terantang \\
\hline & 5 & Kalalawit Merah & Uweh \\
\hline & 6 & Kalalawit Merah & Terantang \\
\hline & 7 & Akar Kuning & Sagagulang \\
\hline & 8 & Akar Kuning & Madang Perawas \\
\hline & 9 & Akar Kuning & Daha Merah \\
\hline & 10 & Akar Kuning & Terantang \\
\hline & 11 & Akar Kuning & Bangkinang \\
\hline \multirow[t]{9}{*}{14} & 1 & Bajakah Darak & Punguan \\
\hline & 2 & Kalalawit Putih & Madang Perawas \\
\hline & 3 & Kalalawit Putih & Tutup kabali \\
\hline & 4 & Kalalawit Merah & Katiau \\
\hline & 5 & Akar Kuning & Piais \\
\hline & 6 & Kalalawit Merah & Madang Perawas \\
\hline & 7 & Kalalawit Merah & Madang Perawas \\
\hline & 8 & Kalalawit Merah & Meranti padi \\
\hline & 9 & Kalalawit Merah & Kelanis \\
\hline \multirow[t]{11}{*}{15} & 1 & Kalalawit Merah & Kamasira \\
\hline & 2 & Akar Kuning & Bintan \\
\hline & 3 & Kalalawit Putih & Sagagulang \\
\hline & 4 & Bajakah Darak & Sagagulang \\
\hline & 5 & Bajakah Darak & Terantang \\
\hline & 6 & Kalalawit Merah & Ramin \\
\hline & 7 & Kalalawit Merah & Daha Merah \\
\hline & 8 & Kalalawit Merah & Madang Perawas \\
\hline & 9 & Kalalawit Merah & Tampang gagas \\
\hline & 10 & Kalalawit Merah & Tutup kabali \\
\hline & 11 & Kalalawit Putih & Daha Merah \\
\hline
\end{tabular}

